\title{
Pengaruh Model Pembelajaran Think Pair Share Terhadap Keaktifan dan Hasil Belajar IPA
}

\author{
Putri Fitriati Nurjannah \\ PGSD, Fakultas IImu Pendidikan, Universitas PGRI Semarang \\ email: putri.fitriati@yahoo.com
}

\begin{abstract}
ABSTRAK
Penelitian ini bertujuan untuk mengetahui pengaruh model pembelajaran think pair share terhadap keaktifan dan hasil belajar IPA Kelas III SDN Kedungrejo 02 Tunjungan Blora. Menggunakan metode Pre-Eksperimental Design model One-Group Pretest-Posttest Design. Hasil posttest keatktifan memiliki rata-rata lebih tinggi yaitu 79,45 serta pretest 71,80 . Berdasarkan perhitungan hipotesis menggunakan uji t didapatkan 12,296 dengan 2,06 disimpulkan thitung>ttabel H0 ditolak. Sedangkan analisis data hasil belajar siswa diperoleh rata-rata pretest sebesar 37,60 dan posttest 77,40. Data tersebut didukung oleh analisis uji-t didapatkan thitung 36,232 dengan 2,06 disimpulkan thitung >ttabel $\mathrm{HO}$ ditolak Maka dapat disimpulkan bahwa ada pengaruh signifikan model pembelajaran think pair share terhadap keaktifan dan hasil belajar IPA kelas III.
\end{abstract}

Kata kunci : Think Pair Share, Hasil belajar

\begin{abstract}
This study aims to determine the effect of think pair share learning model on the activeness and learning outcomes of Science Class III at SDN Kedungrejo 02 Tunjungan Blora. Using the PreExperimental Design method of the One-Group Pretest-Posttest Design model. The effective posttest results have a higher average of 79.45 and pretest of 71.80 . Based on the calculation of the hypothesis using the t test obtained t_count 12,296 with $t$ _ (table) 2.06 concluded that $t$ count $>t$ table $\mathrm{HO}$ is rejected. While the analysis of student learning outcomes data obtained an average pretest of 37.60 and posttest 77.40. The data is supported by t-test analysis found t count 36,232 with t_ (table) 2.06 concluded that $\mathrm{t}$ count $>\mathrm{t}$ table $\mathrm{HO}$ is rejected. It can be concluded that there is a significant effect of think pair share learning model on activeness and learning outcomes of science class III
\end{abstract}

Keywords:Think Pair Share, learning outcomes 


\section{Pendahuluan}

Pendidikan adalah pengaruh lingkungan atas individu untuk menghasilkan perubahan yang tetap (permanen) didalam kebiasaan tingkah-lakunya, pikirannya, dan sikapnya (Sir Godfrey Thompson, 1957) dalam buku Soegeng Ysh, (2017 : 64). Belajar adalah suatu proses usaha yang dilakukan seseorang untuk memperoleh perubahan tingkah laku yang baru secara keseluruhan, sebagai hasil pengalamannya sendiri dalam interaksi dengan lingkungannya (Slameto, 2003 : 2).

Mata pelajaran IPA dianggap sulit oleh sebagian besar peserta didik, mulai dari jenjang sekolah dasar hingga sekolah menengah. Dalam pembelajaran seringkali siswa mengalami kesulitan, seperti kesulitan memahami konsep pembelajaran sehingga berpengaruh terhadap hasil belajar. Dalam proses belajar mengajar, guru berperan penting untuk mendorong, membimbing, dan memberi fasilitas untuk mencapai tujuan pembelajaran. Guru diharapkan dapat meningkatkan keaktifan siswa dalam pembelajaran agar siswa dapat fokus dalam mengikuti pembelajaran guna meningkatkan hasil belajar siswa.

Berdasarkan hasil observasi dan wawancara dengan guru kelas III SD N Kedungrejo 02 Tunjungan Blora, IPA dianggap sebagai mata pelajaran yang sulit, Siswa masih kurang paham dengan materi dan kurang aktif dalam mengikuti kegiatan belajar mengajar sehingga mempengaruhi hasil belajar siswa. Terbukti dengan masih banyaknya siswa yang memiliki nilai dibawah KKM pada mata pelajaran IPA. Dalam proses pembelajaran guru hanya menerapkan metode pembelajaran ceramah sehingga banyak siswa yang bicara sendiri, mengantuk, dan cenderung bosan dalam pembelajaran yang berakibat pada keatifa dan hasil belajar siswa yang banyak mendapatkan nilai dibawah KKM.

Berdasarkan permasalahan diatas peneliti akan meneliti tentang "Pengaruh Model Pembelajaran Think Pair Share Terhadap Keaktifan Dan Hasil Belajar Siswa Pada Mata Pelajaran IPA Siswa Kelas III SD N Kedungrejo 02 Tunjungan Blora".

\section{Metode}

Metode yang digunakan dalam penelitian ini adalah metode eksperimen. Yaitu metode penelitian yang digunakan untuk mencari pengaruh treatment (perlakuan) tertentu (Sugiyono, 2016:11-12). Teknik analisis data yang digunakan adalah analisis data kuantitatif. Desain penelitian yang digunakan dalam penelitian ini adalah dengan Pre Eksperimental Design dengan model One-Group Pretest-Posttest Design. Penelitian ini dilaksanakan di Sekolah Dasar Negeri Kedungrejo 02 Tunjungan Blora kelas III Semester 1 Tahun Pelajaran 2018/2019. Subjek Penelitian adalah siswa kelas III yang berjumlah 25 orang. Pada desain ini, kelas di beri pre-test untuk mengetahui keadaan awal, selanjutnya kelas diberi perlakuan dengan model pembelajaran think pair share. Tindakan selanjutnya diberi posttest setelah diberi perlakuan.

Teknik pengumpulan data yang digunakan adalah observasi, wawancara, angket dan tes. Obesrvasi merupakan teknik pengumpulan data yang dilakukan dengan pengamatan dan pencatatan secara sistematis, logis, objektif, dan rasional. Teknik wawancara merupakan teknik pengumpulan data menggunakan Tanya jawab. Angket atau kuesioner dilakukan dengan cara memberi seperagkat pertanyaan tertulis kepada responden untuk dijawab. Sedangkan tes digunakan untuk mengetahui kemampuan hasil belajar siswa yang menggunakan lembar soal evaluasi.

\section{Hasil dan Pembahasan}

Penelitian ini dilaksanakan di SD Negeri Kedungrejo 02 Kecamatan Tunjungan Kabupaten Blora pada tanggal 22 Oktober sampai dengan 24 Oktober 2018. Penelitian ini menggunakan 1 kelas dengan jumlah siswa sebanyak 25 siswa. Desain atau rencana penelitian menggunakan One Group Pretest-Posttest Design.

Keaktifan belajar siswa selama proses pembelajaran diamati dengan menggunakan lembar pengamatan yang dapat dilihat pada Tabel 1 
Tabel 1. hasil keaktifan belajar siswa

\begin{tabular}{|c|c|c|c|c|c|}
\hline \multirow{2}{*}{ No } & \multirow[t]{2}{*}{ Indikator } & \multicolumn{2}{|c|}{ Pertemuan ke 1} & \multicolumn{2}{|c|}{ Pertemuan ke 2} \\
\hline & & $\begin{array}{l}\text { Presentase } \\
(\%)\end{array}$ & Kreteria & $\begin{array}{l}\text { Presenta } \\
\text { se }(\%)\end{array}$ & Kriteria \\
\hline 1. & $\begin{array}{l}\text { Turut serta dalam melaksanakan } \\
\text { tugas belajarnya }\end{array}$ & $80 \%$ & Baik & $83 \%$ & Baik \\
\hline 2. & $\begin{array}{l}\text { Terlibat dalam pemecahan } \\
\text { masalah }\end{array}$ & $76 \%$ & Baik & $84 \%$ & Baik \\
\hline 3. & $\begin{array}{l}\text { Bertanya kepada siswa lain atau } \\
\text { kepada guru jika tidak memahami } \\
\text { persoalan yang dihadapinya }\end{array}$ & $69 \%$ & Cukup & $77 \%$ & Baik \\
\hline 4. & $\begin{array}{l}\text { Berusaha mencari berbagai } \\
\text { informasi yang diperoleh untuk } \\
\text { pemecahan masalah }\end{array}$ & $63 \%$ & Cukup & $73 \%$ & Cukup \\
\hline 5. & $\begin{array}{c}\text { Melaksanakan diskusi kelompok } \\
\text { Rata-rata }\end{array}$ & $\begin{array}{l}67 \% \\
71 \%\end{array}$ & $\begin{array}{l}\text { Cukup } \\
\text { Cukup }\end{array}$ & $\begin{array}{l}78 \% \\
79 \%\end{array}$ & $\begin{array}{l}\text { Baik } \\
\text { Baik }\end{array}$ \\
\hline
\end{tabular}

Berdasarkan Tabel 1 dapat diketahui bahwa pertemuan pertama diperoleh rata-rata sebanyak $71 \%$, sedangkan pada pertemuan kedua diperoleh rata-rata sebanyak $79 \%$, maka dapat disimpulkan bahwa adanya pengaruh model pembelajaran think pair share terhadap keaktifan belajar siswa di SD N Kedungrejo 02 Tunjungan Blora.

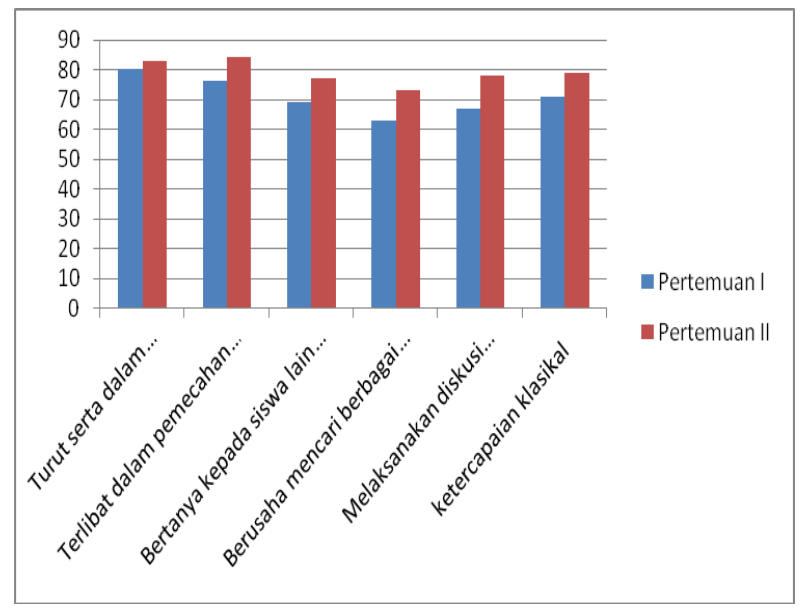

Gambar 1 Presentase Keaktifan Belajar Siswa

Data hasil belajar sebelum diberikan perlakuan dan setelah diberikan perlakuan dapat dilihat dalam Tabel 2

Tabel 2. hasil belajar pretest dan posttest

\begin{tabular}{ccccc}
\hline No & Interval & Pretest & Posttest & Kriteria \\
& & $F$ & $F$ & Sangat baik \\
\hline 1 & $85-100$ & 0 & 7 & Baik \\
2 & $70-84$ & 17 & 13 & Cukup \\
3 & $55-69$ & 8 & 5 & Kurang \\
4 & $40-45$ & 0 & 0 & Sangat kurang \\
5 & $0-39$ & 0 & 0 & \\
\hline
\end{tabular}




Jumlah $25 \quad 25$

Berdasarkan Tabel 2 menunjukkan pretest terdapat 13 siswa dengan kriteria sangat kurang, 7 siswa dengan kriteria kurang, 1 siswa dengan kriteria cukup, dan 2 siswa dengan kriteria baik. Sedangkan posttest terdapat 4 siswa dengan kriteria cukup, 14 siswa dengan kriteria baik, dan 7 siswa dengan kriteria sangat baik. Berdasarkan tabel 2 hasil belajar pretest dan posttest menunjukkan adanya pengaruh setelah diberikan perlakuan menggunakan model pembelajaran think pair share. Maka ada pengaruh hasil belajar IPA menggunakan model pembelajaran Think Pair Share kelas III pada materi Lingkungan di SDN Kedungrejo 02 Tunjungan Blora.

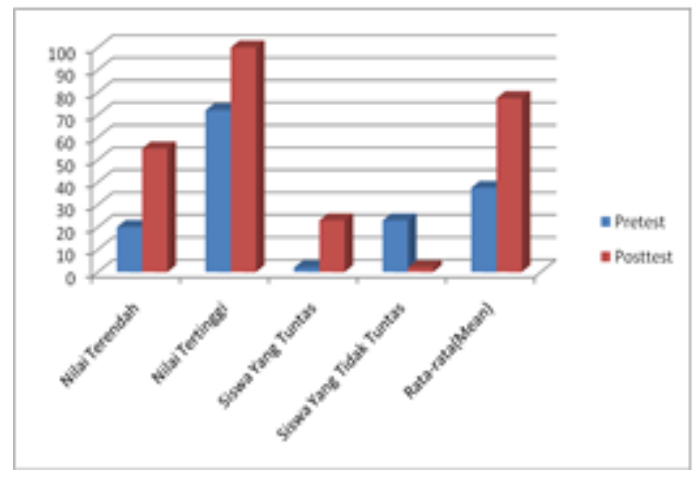

\section{Gambar 2 perbandingan nilai pretest dan posttest}

Setelah melakukan pengujian persyaratan analisis data, maka langkah berikutnya adalah melakukan pengujian hipotesis dengan menggunakan teknik uji-t untuk membandingkan hasil data awal dan akhir serta menentukan ada atau tidaknya perbedaan sebagai akibat dari perlakuan $X$ yaitu pembelajaran dengan menggunakan model pembelajaran think pair share dianalisis dengan menggunakan uji-t serta uji keaktifan dan hasil belajar.

Berdasarkan perhitungan hasil uji t diperoleh data sebagai berikut :

Tabel 3. hasil perhitungan uji T Keaktifan Belajar Siswa

\begin{tabular}{|c|c|c|c|c|c|}
\hline Keaktifan Belajar & Rata-rata & $\Lambda$ & $\mathrm{Md}$ & $t_{\text {hitung }}$ & $t_{\text {tabel }}$ \\
\hline Pertemuan pertama & 71,80 & 2 & & & \\
\hline Pertemuan kedua & 79,45 & 5 & 1, & 10 & 2,00 \\
\hline
\end{tabular}

Berdasarkan Tabel 3 diketahui hasil perhitungan Uji-t keaktifan belajar siswa dimana pada pertemuan pertama dan pertemuan kedua dengan uji-t diperoleh nilai dengan rata-rata 71,80 dan rata-rata pertemuan kedua 79,45. Diperoleh thitung $=12,296$ dan ttabel $=2,06$. Karena thitung $>$ ttabel $(12,296>2,06)$, maka uji-t signifikan. Ini menunjukkan adanya pengaruh dengan menggunakan model pembelajaran think pair share terhadap keaktifan belajar siswa pada mata pelajaran IPA materi lingkungan.

Tabel 4. Perhitungan Hasil Belajar Siswa

\begin{tabular}{llllllll}
\hline Subjek & $\begin{array}{l}\text { Hasil } \\
\text { Belajar }\end{array}$ & $\begin{array}{l}\text { Rata- } \\
\text { rata }\end{array}$ & $\mathrm{N}$ & $\mathrm{Md}$ & $\sum X^{2} d$ & $\mathrm{t}_{\text {hitung }}$ & $\mathrm{t}_{\text {tabel }}$ \\
\hline $\begin{array}{l}\text { Kelas III SDN } \\
\text { 02 }\end{array}$ & $\begin{array}{l}\text { Pretest } \\
\text { Posttest }\end{array}$ & $\begin{array}{l}37,60 \\
77,40\end{array}$ & 25 & 39,80 & 36,232 & 36,232 & 2,06 \\
\hline
\end{tabular}


Berdasarkan Tabel 3 diketahui bahwa rata-rata pada kondisi awal sebelum diberi perlakuan sebesar 37,60, sedangkan rata-rata setelah diberi perlakuan sebesar 77,40. Dari data analisis uji $\mathrm{t}$ diperoleh $\mathrm{t}_{\text {hitung }}=36,232$ selanjutnya dibandingkan dengan $\mathrm{t}_{\text {tabel }}=2,06$ dengan taraf signifikan 5\%. Hasil ini menunjukkan bahwa $t_{\text {hitung }}>t_{\text {tabel }}$ yaitu 36,232> 2,06 maka Ho ditolak dan Ha diterima, sehingga dapat disimpulkan bahwa hasil belajar sebelum dan setelah menggunakan model pembelajaran think pair share berbeda. Dengan adanya perbedaan, artinya ada pengaruh model pembelajaran think pair share terhadap hasil belajar IPA materi lingkungan siswa kelas III SD Negeri Kedungrejo 02 Blora.

Hal ini memperkuat penelitian sebelumnya yang telah dilakukan oleh Winantara, Daniel, \& Jayanta, Laba (2017). "Penerapan Model Pembelajaran TPS Untuk Meningkatkan Hasil Belajar IPA Siswa Kelas V SD No 1 Mengwitani Tahun Pelajaran 2016/2017" yang sama-sama mengkaji model pembelajaran Think Pair Share dan hasil belajar siswa dan Ariantini, Afri, dkk. (2017) yang berjudul "Pengaruh Model Pembelajaran Think Pair Share Terhadap Hasil Belajar IPA Siswa Kelas V SD Gugus II Kecamatan Melaya" yang samasama mengkaji model pembelajaran dan hasil belajar.

\section{Simpulan dan Saran}

Berdasarkan hasil penelitian yang dilakukan dapat disimpulkan bahwa ada pengaruh positif penggunaan model pembelajaran think pair share terhadap keaktifan dan hasil belajar IPA siswa kelas III SDN 02 Kedungrejo. Ada pengaruh model pembelajaran think pair share terhadap keaktifan belajar IPA materi lingkungan kelas III SD Negeri Kedungrejo 02 Blora. Hal ini terbukti pada analisis akhir dengan uji-t yaitu diperoleh thitung $=12,296>$ ttabel $=2,06$ sehingga dapat diartikan bahwa uji t keaktifan belajar signifikan sehingga Ho ditolak.. Berdasarkan perhitungan tersebut maka dapat disimpulkan adanya perbedaan rata-rata nilai pertemuan pertama dan pertemuan kedua.

Ada pengaruh model pembelajaran think pair share terhadap hasil belajar IPA materi lingkungan kelas III SD Negeri Kedungrejo 02 Blora. Hal ini terbukti pada analisis akhir dengan uji-t diperoleh thitung $=36,232>$ ttabel= 2,06 sehingga dapat diartikan bahwa uji $t$ hasil belajar signifikan sehingga Ho ditolak. Berdasarkan perhitungan tersebut maka dapat disimpulkan adanya perbedaan rata-rata nilai pertemuan pertama dan pertemuan kedua. Oleh karena itu, dapat disimpulkan bahwa model pembelajaran think pair share berpengaruh terhadap keaktifan dan hasil belajar IPA materi Lingkungan siswa kelas III SD Negeri Kedungrejo 02 Blora.

\section{Daftar Pustaka}

Adi Cahya Saputra, Wahyu. Penerapan Model Pembelajaran TPS untuk meningkatkan Minat belajar IPA Materi benda dan sifatnya siswa kelas IV SDN Sambirejo 148 Surakarta Tahun Ajaran 2014/2015. Diss. Universitas Muhammadiyah Surakarta, 2015.

Al-Tabany, Trianto. 2014. Mendesain Model Pembelajaran Inovatif, Progresif, Dan Kontekstual, Jakarta : Prenadamedia Group.

Ariantini, Afri, dkk. 2017. Pengaruh Model Pembelajaran Think Pair Share Terhadap Hasil Belajar IPA Siswa Kelas V SD Gugus II Kecamatan Melaya Tahun Pelajaran 2016/2017, e-Journal PGSD Universitas Pendidikan Ganesha Mimbar PGSD Vol: 5 No: 2 Tahun: 2017.

Arifin, Zainal. 2014. Penelitian Pendidikan, Bandung : Rosdakarya.

Arikunto, Suharsimi. 2010. Prosedur Penelitian Suatu Pendekatan, Jakarta : Bumi Aksara.

Arikunto, Suharsimi. 2015. Dasar-Dasar Evaluasi Pendidikan, Jakarta : Bumi Aksara. 
Darsono, M. 2000. Belajar Pembelajaran, Semarang : IKIP Semarang Press.

Hadi, Sutrisno. 2015. Statistik, Yogyakarta : Pustaka Pelajar.

Hamdani. 2011. Strategi Belajar Mengajar, Bandung : Pustaka Setia.

Hariyono. 2013. Penerapan Pembelajaran Kooperatif Model Think Pair Share Untuk Meningkatkan Keaktifan Belajar IPA Melalui Media Flash Movie Siswa Kelas IV SD Negeri Karangrejo Tahun Pelajaran 2012/2013. Universitas Muhammadiyah Surakarta. http://eprints.ums.ac.id/id/eprint/25454

Naimah, Alfiati, and Utami Widiati. "Penerapan Model Pembelajaran Think Pair Share (TPS) Untuk Meningkatkan Hasil Belajar IPA Kelas V SD”. Jurnal Pendidikan Prasekolah. 1.1 (2017).

Purwanto. 2014. Evaluasi Hasil Belajar, Yogyakarta : Pustaka Belajar.

Rusman. 2014. Model-Model Pembelajaran Mengembangkan Profesionalisme Guru, Jakarta : Rajawali Pers.

Rusman. 2016. Model-model Pembelajaran, Jakarta : PT Raja Grafindo Persada.

Sardiman. 2007. Interaksi \& Motivasi Belajar Mengajar, Jakarta : PT Raja Grafindo Persada.

Shoimin, Aris. 2014. 68 Model Pembelajaran Inovatif Dalam Kurikulum 2013, Yogyakarta : Ar-Ruzz Media.

Slameto. 2013. Belajar Dan Faktor-faktor Yang Mempengaruhi, Jakarta : Rineka Cipta.

Soegeng, AY. 2016. Dasar-dasar Penelitian, Yogyakarta : Magnum Pustaka Utama.

Soegeng, AY. 2017. Filsafat Pendidikan, Yogyakarta : Magnum Pustaka Utama.

Sudaryono. 2012. Dasar-dasar Evaluasi Pembelajaran, Yogyakarta : Graha IImu.

Sudjana, Nana. 2014. Penilaian Hasil Proses Belajar Mengajar, Bandung : PT Remaja Rosdakarya.

Sugiyono. 2016. Metode Penelitian Kuantitatif, Kualitatif, \& R\&D, Bandung : Alfabeta.

Suprijono, Agus. 2016. Model-model Pembelajaran Emansipatoris, Yogyakarta : Pustaka Belajar.

Susanto, Ahmad. 2016. Teori Belajar dan Pembelajaran di Sekolah Dasar, Jakarta : Fajar Interpratama Mandiri.

Trianto. 2014. Model Pembelajaran Terpadu Konsep, Strategi, dan Implementasinya dalam Kurikulum Tingkat Satuan Pendidikan ( KTSP), Jakarta : PT Bumi Aksara.

Winantara, Daniel, \& Jayanta, Laba. 2017. Penerapan Model Pembelajaran TPS Untuk Meningkatkan Hasil Belajar IPA Siswa Kelas V SD No 1 Mengwitani, jurnal ilmiah sekolah dasar, Vol.1 (1) pp.9-19. 